\title{
"It's All about Relationships": Enhancing Authentic Learning Processes in Teacher Education
}

\author{
Birgitte Malm \\ Mid Sweden University \\ Sundsvall, Sweden
}

\begin{abstract}
In this article, the significance and consequences of enhancing authentic learning processes within undergraduate teacher education are discussed, inspired by American (liberal arts) contemporary practices. Liberal education can be defined as a higher education that is a cultivation of the whole human being for the functions of citizenship and life in general. In essence, a successful liberal arts programme will be characterized by close student-faculty relationships, small classes, excellent teaching, individual instruction, empathetic advising and personal attention. Nineteen faculty members at a liberal arts college were interviewed about their understanding and experiences of what a liberal arts education entails, how they perceive of the relationship between teaching and research and what in their daily work motivates them. Sentiments expressed included over-commitment and a heavy workload, as well as professional autonomy, meaningful engagement and profound caring and concern for students. Results emphasize the need to reflect on how undergraduate programmes should or need to be constructed and implemented - taking into account the importance of dialogue, feedback and reflection - if the aim is to create competent democratic citizens to be scholars and leaders of the future.
\end{abstract}

Keywords: liberal arts; liberal education; teacher education; teacher educators.

\section{Introduction}

People who have never learned to use reason and imagination to enter a broader world of cultures, groups, and ideas are impoverished personally and politically, however successful their vocational preparation (Nussbaum, 2003, p. 297).

According to The Association of American Colleges and Universities (AAC\&U, 2011, p. 3), liberal education "emphasizes broad knowledge of the wider world (e.g. science, culture and society) as well as in-depth achievement in a specific field of interest. It helps students develop a sense of social responsibility; strong intellectual and practical skills that span all major fields of study, such as 
communication, analytical, and problem-solving skills; and the demonstrated ability to apply knowledge and skills in real-world settings".

Nussbaum (2003, p. 9) raises the questions of what the "cultivation of humanity" requires and what this "inclusive conception" asks us to learn. Three capacities, she contends, are essential to the cultivation of humanity in today's world. In brief, these are:

- The capacity for critical examination of oneself and one's traditions.

- The ability to see oneself not simply as a citizen of some local region or group but as human beings bound to all other human beings by ties of recognition and concern.

- The narrative imagination, i.e. the ability to understand the world from the point of view of the other, which is an essential preparation for moral interaction (ibid.).

In line with Nussbaum, Nolan (2011) describes the standard definition of liberal arts education as "a programme of study designed to foster capacities of analysis, critical reflection, problem solving, communication, computation and synthesis of knowledge from different disciplines". The goal of liberal arts education is "... to provide students with an intellectual, historical, and social context for recognizing the continuity between the past and the future and for drawing on the human capacity of reason to understand human experience, to question the values dimension of human enterprise, and to articulate the results of this process of thinking". Viewed in this context, Nolan contends that "liberal arts education remains the most practical brand of education" (ibid.). This is acknowledged by Schneider (2009):

In a turbulent economy where industries are awash in change and where the combination of inventiveness and judgment is key to any organization's future, the most practical possible education is one that prepares students to make sense of complexity, to chart a course of action that takes full account of context, to engage in continuous learning, and to take responsibility for the quality and integrity of what they do.

The form of teaching that best incorporates these values according to Nussbaum (2003, p. 41) is Socratic teaching, which she insists needs to be built into the programmes: "Given the tremendous importance, for citizenship and life, of producing students who can think clearly and justify their views, a course or courses in philosophy play a vital role in the undergraduate liberal arts curriculum". Building on Stoic writings, Nussbaum (ibid., p. 30) accentuates the following claims: Socratic education is for every human being, it should be suited to the pupil's circumstances, it should be pluralistic (i.e. concerned with a variety of different norms and traditions) and it requires ensuring that books do not become authorities. "Socratic thinking is a social practice" (Nussbaum, 2010, p. 54).

In particular, if education is to be suited to the pupil's circumstances, "it must be concerned with the actual situation of the pupil, with the current state of the pupil's knowledge and beliefs, with the obstacles between that pupil and the 
attainment of self-scrutiny and intellectual freedom (...) All too rarely does anyone ask about the circumstances and background of the students for whom requirements are being designed" (Nussbaum, 2003, p. 32). In order for individual learning to come about, the characteristics mentioned above (small classes, individual instruction, personal attention, empathetic advising) are all essential requisites.

In posing the question of how an undergraduate liberal arts education can follow Socrates' example, Nussbaum (ibid., p. 41) contends that

... the most important ingredient of a Socratic classroom is obviously the instructor. No curricular formula will take the place of provocative and perceptive teaching that arouses the mind. And a dedicated instructor can enliven the thinking of students in almost any curricular setting. Socratic activity can take place in virtually any humanities or social science course, in connection with readings of many different kinds, as long as the instructor knows a good deal about the particular nature of the student body and strives to develop each individual's capacity to reason.

According to Mehrens (2006, p. 122), "A learning environment that supports integrative learning has, in my understanding, its foundation both in the diversity of the curriculum and in the importance attached to teaching, and to the teachers' abilities to adjust education to the specific needs of the students". His conclusion is that "... high quality standards presuppose a solid undergraduate education which not only provides necessary tools for the production of specialized knowledge, but indeed fosters the intellectual, ethical as well as emotional powers of the knowledge producing individual" (ibid., p. 125). Concepts such as moral self-cultivation and academic formation (connecting cognitive and moral competencies) are related to "bildung" or "self cultivation" (see Bohlin, 2013). According to Helskog (2016, p. 2) bildung towards wisdom involves

... reflecting upon and learning from a broad range of lived life experiences, including the experiences of others. Moreover, it should involve personal engagement with philosophical and theoretical literature, guided by questions like 'what touches me in this text?', 'how can I understand myself through these concepts?' and 'what can I learn personally from studying this picture?'. Moreover, it should imply engaging in collaborative experiential learning processes that involve concerning what is happening in us and between us.

Bearing in mind that one of the goals of liberal arts education is to question the values dimension of human enterprise and to articulate the results of this process of thinking (Nolan 2011), and that the Socratic teaching approach is considered an important means of realizing this goal (Nussbaum 2003), several overriding questions related to contemporary teacher training programmes need to be considered: Does contemporary teacher training adequately prepare teachers for work on moral and interpersonal issues that are so essential to their future occupation? Are student teachers given opportunities in which to 
cultivate critical thought, become knowledgeable and empathetic? And, ultimately: How should courses in teacher education be directed toward assisting in the development of personal and professional competences? Inspired by American liberal arts contemporary practices, the experiences of nineteen teacher educators are analyzed and discussed in this study, focusing on their interpretations of what a liberal arts education entails, how they experience the relationship between teaching and research, and how personal sources of motivation influence their work situation.

\section{Enhancing the quality of undergraduate education}

The liberal arts college in this study is described as being committed to liberal learning within a moral and ethical context. It values excellent teaching and close student-faculty relationships. Small classes, individual instruction, empathetic advising and personal attention promote active learning and cultivate intellectual curiosity. Engaged learning is a hallmark of the curriculum, emphasizing research-based experiences in which both students and faculty are involved. In line with the traditional assumptions of liberal education, both inclass and out-of-class programs are designed to develop the whole person intellectually, emotionally, physically, socially and spiritually. As stated by AAC\&U (2002, p. 25), "The philosophy of liberal education depends less on particular subject matter than on an approach to teaching and learning". The importance of the learning environment is stressed by Mehrens (2006, p. 107):

Extra-curricular events, the engagement in community life, student associations of different kinds; all these parts of campus life contribute to create a learning environment that sustains the integration and contextualization of knowledge. "Learning environment" is an important term at liberal arts colleges, and it is worth stressing how it is often referred to as a key concept in accounts of the shift from an Instruction Paradigm to a Learning Paradigm.

At the heart of the undergraduate course of study is the general education programme, ensuring that all undergraduates are introduced to the major methods of inquiry that characterize liberal study. About half of the undergraduate curriculum is designated for the general education programme. Mehrens (2006, p. 82) finds it "admirable that these areas of knowledge are constituted both by methods of pedagogy (like oral communication and writing) and academic subject fields within and beyond the traditional liberal arts and sciences".

Pedagogy in this model of education is clearly not regarded as simply a device beyond the academic fields of education, but is elevated to the same status as the liberal arts and sciences themselves. If we truly want to understand the statement that liberal arts education teaches students how to learn, and how to learn for life, it is important that we acknowledge this essential role of pedagogy within the liberal arts curriculum (ibid.). 
Teacher candidates graduate with a Bachelor of Arts in their major within four years. During their internship they are expected to master various pedagogical strategies, to link theory (research) with practice, and to further refine their knowledge, skills and dispositions.

\section{Method}

In this study, nineteen members of faculty at the Department of Education were interviewed about the personal and professional implications of being a teacher educator at a liberal arts college. I was a visiting lecturer and expressed an interest in meeting the teachers in order to learn more about what a liberal arts education entails. All faculty teachers teach undergraduates and all full-time faculty have Ph.D.'s. Individual interviews lasted between 60-90 minutes and were conducted in the familiar setting of each individual teachers' own office. The interviews were semi-structured, allowing for in-depth discussion. As well as having the "potential for clarifying our ethical commitments and moral aspirations through our language and in our action" (Goodson \& Gill, 2014, p. 94), narrative offers "an opportunity for people to come together, analyze, interpret and develop a "theory" of context - to articulate more clearly the 'situatedness' of our narrative, life, choices and action, which would aid our understanding of how we engage in and with the social world in ways that might open up the possibility for greater change in ourselves, others and beyond" (ibid.). The interviews were transcribed and qualitative content analysis conducted. Themes and categories were identified, based on the following three questions:

(1) What is your understanding of Liberal Arts?

(2) What is your experience of the relationship between teaching and research?

(3) What motivates you?

\section{Liberal Education in practice}

While recognized leaders can make higher achievement a priority, faculty and teachers who work directly with students are the only ones who can make it actually happen (AACEU, 2007, p. 5).

General concepts mentioned by the members of faculty in this study included descriptions of liberal arts as a broad-based and well-rounded education aimed at developing the whole person; giving students the opportunity to explore personal passions and an interest of going 'beyond' what they learned in high school; of being able to invest in different issues from different perspectives and as a preparation to go into the workplace.

\section{What is your understanding of Liberal Arts?}

One faculty leader described Liberal Arts as the core to educating the students to be lifelong learners. He added: "Life is multi-facetted' and said that he was "passionate about this method". "Liberal arts stays with me at all times when 
I'm teaching". This sense of commitment also came across in discussions with the other participants. One said: "I give it my best shot. I believe in this institution"; and another: "I have a sincere love for the institution". A Liberal arts education is described as a way of generating "interest within the students to learn themselves; a desire to continue to learn things and learn about who they are".

One participant expressed the need to nurture the liberal arts tradition while at the same time taking on new forces and issues, such as sustainability. He believes that liberal arts are the best preparation for a high-tech economy and a wide array of ideas and expertise. "I believe that liberal education is relevant in a modern society". He accentuated the fact that by living in close proximity to one another (on campus) students are able to "transcend their own provincialism", which helps them develop an empathic understanding of others. He described liberal arts as presuming a holistic view of education and of nurturing the whole person, "maturing as a person, a thinker, a student" over the span of four years. "We're in the business of cultivating young people to be leaders. We're not in a hurry. We're no diploma industry".

These participants however also voiced concerns as to the future of liberal arts colleges. "They have got to make themselves more relevant. You need to make a claim for your relevance". Inter-disciplinary action in the general education requirements and thinking across disciplines were suggested; "remove department ownership" and "facilitate and embrace the value of interaction". What is needed is "value that is marketable, that industries recognize. We have to continue to make our case".

"University life in the US is facing challenges from politics and accountability. This will give us pause to consider and be active. We need to get the general population to understand what it is we do". Having a Department of Education within a liberal arts college offers many challenges. "We're the new kids on the block. We still have to earn our place among the disciplines".

What is your experience of the relationship between teaching and research?

Teaching was described by one of the participants in the study as being "the most important thing here". "This is a teaching place. I love teaching and working with students. I enjoy what I do. Research and doing in classrooms improves teaching".

Most participants explained that, due to the high teaching load, there is not much time over for doing research. However, as someone stated, "You can't be a good teacher without being a good researcher. Subject matter changes and current research is important to be effective. At this college the most important thing is teaching; research is second". Another was content to regard her research as being based on her supervision, "... there's a close relationship". Most however, feel that teaching and research go together. "If we don't do research we won't know how to teach"; "We need to be constant learners and researchers to better our teaching"; "Teaching and research are interchangeable. Teachers are the most natural researchers". Or as one of the participants explained: "These are fundamentally linked. It's difficult to think of the two as separate. The best teachers are those who are able to maintain some sort of research agenda. Researchers are better if they teach. Higher education liberal 
arts colleges do a good job of that combination". This is confirmed by another: "I do believe that liberal arts offer opportunities for faculty to engage in research that spills over into their teaching. You invest so much of your life, if you're a passionate teacher. You live it - the relationship in-between".

Scholarship was defined as a way of promoting the profession by creating new knowledge and finding ways in which to apply that knowledge. "Developing and creating curriculum is scholarship; taking what has been learnt through reflection and applying it in new contexts". Or: "I'm not so much researcher as I am scholarly: reading the research, synthesizing, making it understandable to the right people".

Teaching, scholarship and service were on the whole seen as informing each other. As one participant concluded, "Either you love it or you don't do it. And you have to love it! That's why we're so over-committed!"

\section{What motivates you?}

When asked for what motivates them, many of the participants mentioned flexibility, freedom and autonomy. As emphasized by Mehrens (2006, p. 94):

One of the most important factors behind the development of teaching at American colleges is the fact that teachers are constantly encouraged to develop new courses within General Education. It is evident that this encouragement prevents the curriculum from remaining in a static shape. It promotes change and development, just as it nurtures an ongoing discussion about the aims and directions of the education, and about its relation to society and the world. Apart from this, the continuous development of new courses functions as an important stimulation for the development of knowledge among teachers. Through this demand for changes of the curriculum, teachers are encouraged to invest their own unique expertise into the education of the college, as well as to develop their own competence.

Sharing meaningful experiences with students and colleagues was very important: "To feel that I'm playing a unique role in the department and at the university. To impact the development of the students I serve here. I think that what I do is very important". An overall commitment to students and to teaching was central to these participants' feelings of well-being, as is evident in the following citations:

My students give me energy. They make me want to start over again, and to keep on trying.

I love my students. They're a blast. I haven't given up on young people yet. There's still hope.

You need to find a balance between being nice and having high expectations. Students need to feel that they are liked. 
Teaching is my passion. When we make the students believe in themselves. I can make a difference in a simple human life. When they leave here knowing that they can also make a difference.

I love what I do. I don't always see this as a job - it's my life.

Helping students to become themselves; preparing them to be scholars and leaders. I still enjoy what we are doing here at the department, despite the headaches!

I get excited when the students get excited. I'm eager to share.

Being in an environment that is completely stimulating every single day. I love coming to work.

My motivation is that the work we are doing will help young people out there, directly or indirectly. What I've learnt over the years - it's all about relationships. Teaching is my life. I've been blessed.

It is evident that these faculty members are deeply committed to their students and to teaching. There are feelings of obvious contentment and satisfaction regarding their work place and situation.

\section{Nurturing meaningful relationships}

Overall, there seems to be a natural integration between the faculty members' personal and professional selves. They display authentic care and concern; they feel motivated and express gratitude in being able to make a difference in the lives of others. According to Laursen (2004, p. 161, my translation), "Authenticity and professionalism are not each other's opposites; on the contrary, authenticity is professionalism at the highest level, where there is no division between person and professionalism". And: "Professional authenticity ensues when the professionals' own underlying values are in alignment with the values of the profession, and if the professional acts in accordance with these values" (ibid., p. 181). Laursen identifies the following competences related to authentic teachers: personal commitment, embodiment of the task, realistic intentions concerning teaching, working in contexts where these intentions can be realized, respect for students, intense cooperation with colleagues and a continual striving towards personal and professional development. "If we understand authenticity as constituting a state of 'being' in a constant process of 'becoming', that is, as a moral goal in itself (e.g., self-fulfillment as a teacher) as well as constituting a moral means towards attaining other goals (e.g., through positive relations with students), we must recognize the value that the concept of authenticity has on an individual level as well as acknowledge its relevance in a wider (societal) context. Psychologically, philosophically and pedagogically the concept of authenticity can be used to deepen our understanding of ourselves and others" (Malm, 2008, p. 385).

Kreber (2013, p. 5) argues that "being a scholar of teaching is an ongoing transformative learning process that is intimately bound up with becoming authentic". She writes: 
When we engage in (the scholarship of) teaching authentically we seek to enrich not only the students' academic learning, our repertoire of teaching practices and the knowledge base of teaching. We also have an interest in who we and our students are becoming and how, through our work, we can contribute to the common good. Thus, through authentic engagement in (the scholarship of) teaching we demonstrate that the world matters to us (ibid., p. 13).

According to Hodge, Baxter Magolda and Haynes (2009, p. 19) active, engaged and collaborate learning requires educators to

... move away from the traditional role of the expert or avoid the tendency to seek students' approval and instead push students to gain intellectual, relational, and personal maturity through continuous feedback and high expectations. Educators can help students become more internally focused by validating them as thinkers and burgeoning scholars, presenting thorny problems and topics that lend themselves to multiple legitimate perspectives, introducing them to multiple legitimate perspectives, introducing them to competencies needed to address those topics, and helping them form, and accept responsibility for, their own decisions and actions in ways that are consistent with their own identities.

Teaching involves human interaction and as such has an emotional dimension. As Hargreaves (1998, p. 835) contends, teaching is "an emotional practice". He describes the emotional bond teachers have with their students as a central influence with regard to their choice of method, teaching context and practice. He writes: "... the social and emotional goals they wanted to achieve as they taught those students, shaped and influenced almost everything they did, along with how they responded to changes that affected what they did. Teachers wanted to become better so they could help their students more effectively" (ibid., p. 845). From an educational point of view, it is important to at least acknowledge that emotions are bodily felt, meaningful experiences, triggered by interactions with the material, social and cultural world. As such the meaning of emotions is to a large extent relational, socially constructed and reflecting cultural norms as well as power structures (Kelchtermans \& Deketelaere, 2016, pp. 431). Kelchtermans and Deketelaere (ibid., pp. 452) conclude that:

- The emotional is linked to the fundamental relational nature of teaching and therefore of learning to teach.

- The emotional dimension of becoming a teacher is deeply entwined with the moral, the political as well as the technical (or instrumental) dimensions that characterize teaching and schooling.

- The emotional dimension in becoming a teacher is closely related to the fact that this learning process also involves one's self-understanding (sense of 'self' or 'identity'). Becoming a teacher demands developing a professional self-understanding as a (future) teacher. 
Kelchtermans (2005, p. 997) describes vulnerability as a structural condition in which educators/teachers find themselves and which "constitutes the very possibility for the 'pedagogical' to happen in the relationship between teachers and pupils". He concludes that such an encounter "makes the teacher feel that they are really 'making a difference as a person' in the student's life. Joy, pride, existential personal fulfilment are the emotions that go with it" (ibid., p. 999). Vanassche and Kelchtermans (2016, p. 365) identify two constantly interacting concepts central to our understanding of professional development: teacher educators' self-understanding and their professional working context. Kelchtermans contends that teacher educators face the same vulnerability as has been identified with teachers. Vulnerability "is not so much to be understood as an emotional state or experience (...) but as a structural characteristic of the profession" (Kelchtermans, 2009, p. 265).

Kelchtermans and Deketelaere (2016, p. 430) write that "the emotions are related to learning processes, curriculum arrangements, pedagogical interventions, and more fundamentally to the relational nature of education and of becoming a teacher (...) emotions need to be understood in context, because they are triggered by a wide variety of conditions, interactions and experiences". One of the characteristics of relational pedagogy is the fact that "educational relation is different from any other; its nature is transitional. Educational relation exists in order to include the student in a wider web of relations beyond the limits of the educational relation" (Bingham \& Sidorkin, 2004, p. 6). As Vanassche and Kelchtermans (2014, p. 121) so aptly describe it:

The relationship these teacher educators sought to establish with their student teachers resembled the envisaged qualities of the relationship between the student teachers and their future students; not just professionals to train, but persons to support in their full development as human beings. For the teacher educators of 'pedagogues', the personal and professional self were seen as intertwining. Furthermore, the attention to the "whole person" expressed a concern for student teachers' emotional well-being.

In a study by Smulyan (2007, p. 80), teacher education students explain how their experiences at a liberal arts college

... provided them with frameworks for understanding teaching and learning that encouraged them to become critical educators. They credit the general liberal arts experience with helping them recognize multiple intellectual worlds and ways of knowing and with giving them opportunities to participate in the critique and construction of knowledge. These students also recognize their teacher education program, embedded within the values and constructs of the liberal arts setting, for helping them understand the political, historical, and institutional frameworks within which they, as teachers, will work. They explain how this model of teacher education within the liberal arts challenged them to consider both the constraints on education in our society and the potential for teachers to participate in the movement towards social justice. 
The sentiments described above are in alignment with the intentions and holistic approach expressed by a leading member of faculty interviewed in the present study: "Of course our first concern is developing the intellectual capacities of our students, but our main concern is their development as human beings. We strive to ensure that our students are exposed to new ideas and theories, but we also have an uncommon interest in the exploration of values". He concludes: "This means asking students to consider who they are and what they are going to be in life. Not simply what they are going to do, but what they are going to be - inside themselves and among themselves".

\section{Discussion}

The professions and liberal learning are united because the first is composed of the disciplines of the second and because both address issues of living. In the deepest sense, both are applied knowledge (Rothblatt, 2003, p. 47).

As is clearly conveyed by the members of faculty interviewed in this study, nurturing meaningful relationships is essential to maintaining what Kreber (2013, p. 5) describes as ongoing transformative processes that are intimately bound up with becoming authentic.

Consequently, if we are to aspire towards lifelong learning in educational settings, "we need to acknowledge the significance that relationships, dialogues and personal dispositions have for the personal and professional development of prospective teachers" (Malm, 2017, p. 84). The European Colleges of Liberal Arts and Sciences (ECOLAS, What is Liberal Arts and Sciences) emphasize the fact that personal and close interactions between students and teachers are indispensable to these learning processes.

Teacher educators "are present at every stage of the teacher's career. They teach teachers how to teach, and facilitate and encourage their learning, both explicitly, via lectures, seminars and tutorials, and implicitly, by modelling in their own teaching what it means to be a professional teacher" (European Commission, 2013, pp. 6). The European Commission stresses the need to strengthen links between teacher educators, practicing teachers, the world of work and other agencies. The fact that teachers act as role models necessitates that the profession fully reflects the diversity of the society in which it operates. "Those responsible for educating teachers (and for educating teacher educators) should possess practical experience of classroom teaching and have attained a very high standard in the skills, attitudes and competences demanded of teachers" (European Commission, 2007, p. 15).

The European Colleges of Liberal Arts and Sciences (ECOLAS, Bologna Process $\mathcal{E}$ Liberal Education) believes that it is during the undergraduate phase of higher education that a strong academic basis should be laid; the quality of the bachelor degree is instrumental in attracting and creating a pool of European talents. The primary mission of ECOLAS is thus to promote undergraduate liberal arts and sciences programmes across Europe.

According to Shulman (2011, p. x), "the most common underlying malady besetting undergraduate education (...) is the disintegrated character of the learning experience". The dilemma of universities is that "when the educational goal is to teach students to become adept at practical reasoning in the presence 
of problems of the real world, the very separations that make the growth of knowledge possible make its educational use problematic. (...) The core problem is not specialization and disciplinary investment per se. The problem is that the parts remain separate and distinct with no complementary strategy or incentive" ... (ibid.). He suggests a strategy of reciprocal integration. This concept argues strongly that "the liberal arts must be professionalized, must be framed and taught in the context of practical problems, at least as much as practical learning needs to be enriched, nuanced, and critiqued through the lenses of the ideas and perspectives of the liberal arts" (ibid., p. xi). As Osguthorpe (2013, p. 27) contends: "Moral and ethical dispositions occupy an important dimension of the moral work of teaching, and they need to command more attention in the teacher education curriculum and conversation". Walker, Roberts and Kristjansson (2015, p. 79) describe "the striking disharmony between the constantly evolving legitimating principles of character education and their continued non-appearance on education-policy and teacher-training agendas".

Essential learning outcomes in preparing students for twenty-first-century challenges are described as follows (AAC\&U, 2011, p. 7):

(1) Knowledge of Human Cultures and the Physical and Natural World: engagement with contemporary and enduring questions.

(2) Intellectual and Practical Skills: practiced progressively across the curriculum.

(3) Personal and Social Responsibility: active involvement with real-world challenges and diverse communities.

(4) Integrative and Applied Learning: applying knowledge, skills, and responsibilities to new settings and complex problems.

As stated by the AACU (2007, p. 50): "Ultimately, it is the quality of learning, not the possession of a diploma, that will make all the difference - to individuals, to an economy dependent upon innovation, and to the integrity of the democracy we create together".

Although lifelong learning has been stipulated as being an essential element of the European Higher Education Area, Schneider (2009) establishes the fact that, due to the "criterion-referenced standards for specific disciplines that is being attempted through the Bologna Process with its 'tuning' of cross-national degree requirements (...) it does not promise European students an integrative, cross-disciplinary liberal education that is clearly tied to the responsibilities of democratic and global citizenship. Absent that promise, both its vision and its precision are insufficient"... writes: "Most researchers believe that the quality of teaching cannot be ascertained only by indicators such as academic degrees, the number of years of study, experience, grades, and academic or pedagogic abilities. Intellectual teachers must express themselves verbally, and have a broad education which enables them to act as agents of culture and universal knowledge". Thus, as Mehrens (2006, p. 124) contends, "It is vital that learning outcomes should not be thought of only in terms of concrete skills and career opportunities, but also in terms of the ethical dimension of knowledge within the humanities". 
As Nussbaum (2003, p. 301) argues, it is "very urgent right now to support curricular efforts aimed at producing citizens who can take charge of their own reasoning, who can see the different and foreign not as a threat to be resisted, but as an invitation to explore and understand, expanding their own minds and their capacity for citizenship". Building on personal experience, she notes that liberal arts courses have been introduced in countries such as the Netherlands, Sweden, India, Germany, Italy and Bangladesh. She writes: "Outside the United States, many nations whose university curricula do not include a liberal arts component are now striving to build one, since they acknowledge its importance in crafting a public response to the problems of pluralism, fear, and suspicion their societies face" (2010, p. 125).

\section{Concluding remarks}

In promoting lifelong learning and good citizenship we need to acknowledge the importance of liberal learning and incorporate its value system and practical approach into our teacher training programmes. It is of great importance "that the contents of teacher-training programmes should be developed so that they correspond more fully with the needs that newly-qualified teachers have. This mainly involves the skills that form part of social competence but also knowledge of the problems that pupils have and the ability to deal with them professionally" (Malm, 2009, p. 84). And, similarly, if we are to construct a teacher education that contributes to developing students' capacities for critical thinking and which fosters a complex understanding of the world and its citizens while at the same time cultivating the students' capacity for empathy, we need to adopt a holistic perspective to personal and professional development (Malm, 2011). As emphasized by Malm and Löfgren (2007, p. 18), "The schools of tomorrow need to focus on goals such as promoting conflict literacy, empathic competence, respect for the individual and democratic values. With a holistic approach to lifelong learning, the school has an increased responsibility for social training, upbringing and educating the 'good' citizen". Nussbaum (2010, p. 143) stresses the crucial importance of the humanities and the arts in making "a world that is worth living in, people who are able to see other human beings as full people, with thoughts and feelings of their own that deserve respect and empathy, and nations that are able to overcome fear and suspicion in favor of sympathetic and reasonable debate". If we are to consider applying the value system and practical approach of a Liberal Education, we need to heed Rothblatt (2003, p. 10) when he cautions: "Precisely because other nations, not only in Europe but now also in Asia, regard the American experience of liberal education as a guide to their own educational futures, simplification must be avoided. Short-cuts are impossible". As he so wisely contends (ibid.), "Each nation must consider, with glances toward the others, how best to incorporate the principles and structures of a liberal education into its own history and culture". 


\section{References}

Association of American Colleges and Universities (AAC\&U). (2002). Greater Expectations: A New Vision for Learning as a Nation Goes to College. Available at: https://www.aacu.org/sites/default/files/files/publications/GreaterExpectations.pdf

Association of American Colleges and Universities (AAC\&U). (2007). College Learning for the New Global Century. Available at: https://www.aacu.org/sites/default/files/files/LEAP/GlobalCentury_final.pdf

Association of American Colleges and Universities (AAC\&U). (2011). The LEAP Vision for Learning. Outcomes, Practices, Impact, and Employers' Views. Available at: https://www.aacu.org/sites/default/files/files/publications/LEAP_Vision_Summary.pdf

Bingham, C. \& Sidorkin, A. (Eds.) (2004). No Education Without Relation. New York: Peter Lang.

Bohlin, H. (2013). Bildung and Intercultural Understanding. In Intercultural Education, 24(5), 391-400. http://dx.doi.org/10.1080/14675986.2013.826019

European Colleges of Liberal Arts and Sciences (ECOLAS). What is Liberal Arts and Sciences. Available at http://www.ecolas.eu/eng/?page_id=15 Accessed 9 July 2016.

European Colleges of Liberal Arts and Sciences (ECOLAS). Bologna Process \& Liberal Education. Available at http://www.ecolas.eu/eng/?page_id=13 Accessed 9 July 2016.

European Commission. (2013). Supporting Teacher Educators for better learning outcomes. http://ec.europa.eu/dgs/education_culture/repository/education/policy/sch ool/doc/support-teacher-educators_en.pdf

European Commission (2007). Improving the Quality of Teacher Education. Communication from the Commission to the Council and the European Parliament. Available at http://www.atee1.org/uploads/EUpolicies/improving_the_quality_of_teacher _education_aug2007.pdf

Goodson, I. \& Gill, S. (2014). Critical Narrative As Pedagogy. London: Bloomsbury.

Hargreaves, A. (1998). The emotional practice of teaching. Teaching and Teacher Education. An International Journal of Research and Studies, 14(8), 835-854.

Helskog, G. (2016). Bildung towards wisdom, through philosophical dialogue in teacher education. Arts $\mathcal{E}$ Humanities in Higher Education. 0(0), 1-15. https:// doi.org/10.1177/1474022216670609

Hodge, D., Baxter Magolda, M., \& Haynes, C. (2009). Engaged Learning: Enabling SelfAuthorship and Effective Practice. Available at http://files.eric.ed.gov/fulltext/EJ871317.pdf

Kelchtermans, G. \& Deketelaere, A. (2016). The Emotional Dimension in Becoming a

Teacher. In J. Loughran \& M. Hamilton (Eds.). International Handbook of Teacher Education. Volume 2. Singapore: Springer.

Kelchtermans, G. (2009). Who I am in how I teach is the message: self-understanding, vulnerability and reflection. Teachers and Teaching: theory and practice. (15)2, 257272. https:// doi.org/10.1080/13540600902875332

Kelchtermans, G. (2005). Teachers' emotions in educational reforms: Self-understanding, vulnerable commitment and micropolitical literacy. Teaching and Teacher Education 21(8), 895-1006. https:/ / doi.org/10.1016/j.tate.2005.06.009

Ketko, T. Teachers in Multi-Cultural Societies: Excellence and Leadership. International Journal of Learning, Teaching and Educational Research. (16)4, 54-66.

Kreber, C. (2013). Authenticity In And Through Teaching In Higher Education. The transformative potential of the scholarship of teaching. New York: Routledge. 
Laursen, P. F. (2004). Den autentiska läraren. Bli en bra och effektiv undervisare - om du vill. [The authentic teacher. Become a good and effective educator-if you want to]. Stockholm, Sweden: Liber AB.

Malm, B. (2017). "We Need to Give the Profession Something that No One Else Can": Swedish Student Teachers' Perceptions and Experiences of their Preschool Teacher Training Programme. International Journal of Learning, Teaching and Educational Research, 16(9), 73-87. https://doi.org/10.26803/ijlter.16.9.6

Malm, B. (2011). En helhetssyn på lärarkompetens [A Holistic Approach to Teacher Competence]. I A. Burman \& P. Mehrens (Red.), Det goda lärandet: En antologi om liberal arts education [Good learning: An Anthology of Liberal Arts Education], 129-141. Lund: Studentlitteratur.

Malm, B. (2009). Towards a new professionalism. Enhancing personal and professional development in Teacher Education. Journal of Education for Teaching. International Research and Pedagogy, 35(1), 77-91. https://doi.org/10.1080/02607470802587160

Malm, B. (2008). Authenticity in teachers' lives and work. Some philosophical and empirical considerations. Scandinavian Journal of Educational Research, 52(4), 373386. https://doi.org/10.1080/00313830802184525

Malm, B. \& Löfgren, H. (2007). Empowering students to handle conflicts through the use of drama. Journal of Peace Education, 4(1), 1-20. https:// doi.org/10.1080/17400200601171164

Mehrens, P. (2006). Learning from Liberal Arts. Ideas for the Improvement of Undergraduate Education in Sweden. Uppsala Universitet: Avdelning för utveckling av pedagogik och interaktivt lärande. Rapport 6.

Nolan, E. (2011). Liberal Arts Education - A Foundation for Success. Available at http://www.champscharter.org/apps/pages/index.jsp?uREC_ID=137364\&tpe $=\mathrm{d} \& \mathrm{pREC} \_\mathrm{ID}=267810$ Accessed 9 July 2016.

Nussbaum, M. (2010). Not for profit. Why democracy needs the Humanities. New Jersey: Princeton University Press.

Nussbaum, M. (2003). Cultivating Humanity. A Classical Defence of Reform in Liberal Education. Cambridge, Massachusetts: Harvard University Press.

Osguthorpe, R. (2013). Attending to Ethical and Moral Dispositions in Teacher Education. Issues in Teacher Education, 22(1), 17-28. https://www.itejournal.org/back-issues/spring-2013/07osguthorpe.pdf

Rothblatt, S. (2003). The Living Arts. Comparative and Historical Reflections on Liberal Education. Washington: Association of American Colleges and Universities.

Schneider, C. (2009). Bologna Plus: The Liberal Education Advantage. In Liberal Education, 95(4). Association of American Colleges and Universities (AAC\&U). Available at: https://www.aacu.org/publicationsresearch/periodicals/clarkaacu-challenge-connecting-liberal-education-realworld Accessed 9 July 2016.

Shulman, L. (2011). In A. Colby, T. Ehrlich, W. Sullivan \& D. Dolle. Rethinking Undergraduate Business Education. Liberal Learning for the Profession. San Francisco, CA: Jossey-Bass.

Smulyan, L. (2007). "The Power of a Teacher": Teacher Education for Social Justice. In C.

Bjork, D. Kay Johnston \& H. Ross (Eds.). Taking Teaching Seriously. How Liberal Arts Colleges Prepare Teachers to Meet Today's Educational Challenges in Schools. New York: Routledge.

Vanassche, E. \& and Kelchtermans, G. (2016). A narrative analysis of a teacher educator's professional learning journey. European Journal of Teacher Education, 39(3), 355-367. https://doi.org/10.1080/02619768.2016.1187127 
Vanassche, E. \& and Kelchtermans, G. (2014). Teacher educators' professionalism in practice: Positioning theory and personal interpretative framework. Teaching and Teacher Education, Vol. 44, 117-127. https://doi.org/10.1080/02619768.2016.1187127

Walker, D., Roberts, M., \& Kristjansson, K. (2015). Towards a new era of character education in theory and in practice. Educational Review, 67(1), 79-96. https://doi.org/10.1080/00131911.2013.827631. 